\title{
IMPLEMENTASI PENGGUNAAN KECERDASAN BUATAN PADA INDUSTRI FINTECH SYARIAH
}

\section{IMPLEMENTATION OF ARTIFICIAL INTELLIGENCE IN THE SHARIA FINTECH INDUSTRY}

\section{Hisyam Rifqi Madani}

Fakultas Hukum Universitas Jember

Email: hisyamrifqimadani@gmail.com

\begin{abstract}
ABSTRAK
Startup syariah terus mengalami perkembangan di seluruh belahan dunia. Fintech lending syariah sendiri yang saat ini sudah berdiri di Indonesia diantaranya adalah indves, syarQ, start zakat, paytren, dan lain-lain. Hingga saat ini, di Indonesia mayoritas perusahaan masih dikuasai financial teknologi konvensional. Dalam situs resmi OJK hingga pada juni 2019 pada data yang telah di paparkan sejumlah 46 perusahaan penyelenggara layanan keuangan telah mendapat ijin resmi OJK dan 100 penyelenggara terdaftar, seiring perkembangannya para layanan fintech tersebut secara bertahap masuk kedalam system keuangan syariah. Keberadaan Dewan Pengawas syariah yang menghambat perkembangan industri fintech lending syariah menyebabkan sedikitnya penyelenggara usaha fintech lending syariah di Indonesia. memperhatikan berbagai macam aspek perkembangan teknologi dan ekonomi yang begitu pesat di Indonesia, pihak Majelis Ulama Indonesia (MUI) mengeluarkan pendapat tentang pertanyaan masyarakat terkait dengan adanya penawaran produk berbasis syariah dari para startup bisnis syariah. Hal ini dilakukan untuk memberi penjelasan tentang berbagai aturan dan ketentuan layanan keuangan berbasis teknologi yang berdasarkan pada syariah islam.
\end{abstract}

Kata Kunci: kecerdasan buatan, fintech, syariah, MUI, OJK. 


\begin{abstract}
Islamic startups continue to experience development around the world. Sharia fintech lending itself that is currently established in Indonesia includes investment, syarQ, start zakat, paytren, and others. Until now, in Indonesia the majority of companies are still controlled by financial technology. In the official OJK website, as of June 2019, the data that has been described is that 46 financial service providers have received official OJK permission and 100 registered operators, along with the development of these fintech services, are gradually entering the Islamic financial system. The existence of the Sharia Supervisory Board which hinders the development of the sharia fintech lending industry has caused at least a few sharia fintech lending business operators in Indonesia. Paying attention to various aspects of rapid technological and economic development in Indonesia, the Indonesian Ulema Council (MUI) issued an opinion on public questions related to the existence of sharia-based product offerings from sharia business startups. This is done to provide an explanation of the various rules and provisions of technology-based financial services based on Islamic sharia.
\end{abstract}

Keyword: Artificial intelligence, fintech, syariah, MUI, OJK.

\title{
PENDAHULUAN
}

Sebagaimana kita ketahui setiap negara mengalami revolusi untuk melahirkan perubahan yang fundamental dan berlangsung cepat. Adanya sebuah revolusi dapat membawa perubahan yang signifikan di masyarakat, baik itu bidang ekonomi, politik, dan budaya. Adapun Revolusi yang terjadi baru-baru ini salah satunya adalah Revolusi industri 4.0. Revolusi ini telah melahirkan inovasi-inovasi baru dalam kehidupan manusia. Teknologi komputer yang berkembang semakin pesat telah menghadirkan entitas unik dalam kehidupan modern manusia, diantaranya Artificial Intelegence. Menurut Budiharto dan Suhartono
AI mencakup bidang yang cukup besar, mulai dari yang paling umum diketahui hingga yang khusus, dari Learning atau Perception hingga pada permainan catur, AI telah membuktikan dirinya dengan menjabarkan teori matematika, mengembangkan penulisan puisi, mengemudikan mobil dan bahkan dapat dengan cepat melakukan diagnosis penyakit dengan akurat.

Menurut Sterling Miller AI merupakan komputasi kognitif yang bisa mengajarkan komputer itu sendiri untuk belajar, bernalar, berkomunikasi, dan membuat keputusan. Meskipun dalam perkembangannya AI dapat 
melakukan berbagai hal yang bisa dilakukan oleh manusia dan bahkan lebih baik lagi. Termasuk menyelesaikan masalah atau tugastugas yang sifatnya lebih kompleks dan membutuhkan kemampuan khusus. Oleh karena itu, penggunaan AI dalam proses pengawasan penerapan prinsip syariah sendiri memiliki potensi manfaat dan efisiensi yang tepat serta kemudahan bagi penggunanya.

Layanan industri jasa keuangan digital atau financial technology semakin beragam jenisnya di masyarakat. Setelah ada uang elektronik (e-payment), asuransi teknologi (insuretech), pinjaman online atau fintech peer to peer (P2P) konvensional, kini mulai berkembang di masyarakat fintech syariah. Sebenarnya, jenis ini termasuk kategori fintech P2P karena inti bisnisnya memberi pendanaan kepada peminjam. Namun, sesuai namanya, fintech syariah menerapkan prinsip-prinsip Islam dalam transaksinya. Sehingga, terdapat perbedaan dalam bunga atau riba, akad, mekanisme penagihan hingga penyelesaian sengketa.

Pada tahun 2016 di wilayah asia tenggara tepatnya di Singapura, memperkenalkan produk fintech syariah capital boost yang sudah memperoleh sertifikat kepatuhan syariah dari Financial Shariah Advisory Consultasy di Singapura, adapun pada tahun 2014 terdapat fintech syariah dari Singapura yang berhasil menguasai pangsa pasar di Indonesia dengan system crowdfunding dan sudah mempunyai layanan keuangan syariah.

Beberapa waktu terakhir Crowdfunding syariah terus mengalami perkembangan di seluruh belahan dunia. Fintech syariah sendiri yang saat ini sudah berdiri di Indonesia diantaranya adalah indves, syarQ, start zakat, paytren, dan lain - lain. Fintech syariah yang memiliki sertifikasi halal dari MUI pertama di Indonesia ialah Paytren pada tahun 2017. hingga saat ini financial technologi di Indonesia masih berada di mayoritas financial teknologi konvensional. Dalam situs resmi OJK hingga pada juni 2019 pada data yang telah di paparkan sejumlah 113 perusahaan penyelenggara layanan keuangan telah mendapat ijin resmi OJK, seiring perkembangannya para layanan fintech tersebut secara bertahap masuk kedalam system keuangan syariah.

Adanya para startup bisnis usaha yang mulai menjalankan bisnisnya dengan mengikuti prinsip-prinsip syariah dan sudah terdaftar pada OJK dan DSN-MUI, mulai dengan cara melihat produk yang akan ditawarkan, kejelasan akad yang digunakan, dan juga aturan-aturan didalamnya sesuai dengan ajaran islam. Dengan memperhatikan berbagai macam aspek dan perkembangan teknologi yang begitu pesat di Indonesia, pihak Majelis Ulama Indonesia (MUI) mengeluarkan pendapat tentang pertanyaan masyarakat terkait dengan adanya 
penawaran produk berbasis syariah dari para startup bisnis syariah. Hal ini dilakukan untuk memberi penjelasan tentang berbagai aturan dan ketentuan layanan keuangan berbasis teknologi yang berdasarkan pada syariah islam.

MUI mengeluarkan Fatwa Dewan Syariah Nasional - Majelis Ulama Indonesia (DSN-MUI) No. 117/DSN-MUI/II/2018 Tentang Layanan pembiayaan berbasis teknologi informasi berdasarkan prinsip syariah. Selain persoalan bunga, fintech syariah juga tidak memiliki metode tersendiri dalam penagihan pinjaman. Seperti diketahui, dalam kegiatan penagihan sering sekali jadi persoalan dimana industri fintech kemudian melakukan perbuatan yang berbahaya bagi konsumennya seperti intimidasi, pencurian dan penyalagunaan data hingga pelecehan seksual. penagihan fintech syariah dilakukan dengan metode inhouse.

\section{METODE PENELITIAN}

Penelitian ini menenggunakan kajian literasi yaitu berasal dari buku-buku, literatur yang berkaitan dalam penelitian yang sedang diteliti.

\section{HASIL PENELITIAN DAN PEMBAHASAN}

\section{Lembaga Pembiayaan Financial Technology}

Berdasarkan keputusan Presiden Nomor 61 Tahun 1988 dan dijabarkan lebih lanjut melalui Keputusan Menteri Keuangan Nomor 1251/KMK.013/1988 tentang Ketentuan dan
Tata Cara Pelaksanaan Lembaga Pembiayaan, Pasal 1, dijelaskan bahwa yang dimaksud dengan lembaga pembiayaan adalah suatu badan usaha yang di dalam melakukan kegiatan pembiayaan dalam bentuk penyediaan dana atau barang modal dengan tidak menarik dana secara langsung dari masyarakat.

Berkaitan dengan lembaga pembiayaan di Indonesia salah satunya adalah Financial Technology (Fintech), adapun pengertian fintech berdasarkan Dorfleitner, Hornuf, Schmitt, \& Weber (2017) Fintech merupakan industri yang bergerak dengan sangat cepat dan dinamis dimana banyak model bisnis yang berbeda. Berdasarkan Hsueh (2017), Teknologi Keuangan juga disebut sebagai fintech, merupakan model layanan keuangan baru yang dikembangkan melalui inovasi teknologi informasi.

Berdasarkan Peraturan Bank Indonesia No.19/12/PBI/2017 tentang Penyelenggaraan Teknologi Finansial (PBI Tekfin) telah ditegaskan definisi yang digunakan oleh BI mengenai fintech hingga kategori dan kriterianya. Definisi Teknologi Fintech dalam Pasal 1 "teknologi finansial adalah penggunaan teknologi dalam sistem keuangan yang menghasilkan produk, layanan, teknologi, dan/atau model bisnis baru serta dapat berdampak pada stabilitas moneter, stabilitas sistem keuangan, dan/atau efisiensi, kelancaran, keamanan, dan keandalan sistem pembayaran". 
Kategori Penyelenggaraan Teknologi

Finansial/Fintech Pasal 3 ayat 1:

1. Sistem pembayaran;

2. Pendukung pasar;

3. Manajemen investasi dan manajemen risiko;

4. Pinjaman, pembiayaan, dan penyediaan modal; dan

5. Jasa finansial lainnya.

Kriteria Teknologi Finansial pasal 3 ayat 2:

1. Bersifat inovatif;

2. Dapat berdampak pada produk, layanan, teknologi, dan/atau model bisnis finansial yang telah eksis;

3. Dapat memberikan manfaat bagi masyarakat;

4. Dapat digunakan secara luas; dan

5. Kriteria lain yang ditetapkan oleh Bank Indonesia.

Berdasarkan definisi Otoritas Jasa Keuangan fintech adalah sebuah inovasi pada industri jasa keuangan yang memanfaatkan penggunaan teknologi. Produk fintech biasanya berupa suatu sistem yang dibangun guna menjalankan mekanisme transaksi keuangan yang spesifik.

\section{Tipe-tipe Financial Technology (Fintech)}

Menurut Hsueh (2017), terdapat tiga tipe Financial Technology, yaitu:

1. Sistem pembayaran melalui pihak ketiga (Third-party payment system).
Contohnya, sistem pembayaran melalui pihak ketiga yaitu cross-border EC, online-to-ofline $\quad(\mathrm{O} 2 \mathrm{O}), \quad$ sistem pembayaran mobile, dan platform pembayaran yang menyediakan jasa seperti pembayaran bank dan transfer.

\section{Peer-to-Peer $(P 2 P)$ Lending}

Fintech lending atau fintech Peer-to-Peer Lending atau layanan Pinjam Meminjam Uang berbasis Teknologi Informasi (LPMUBTI) adalah salah satu inovasi pada bidang keuangan dengan pemanfaatan teknologi yang memungkinkan pemberi pinjaman dan penerima pinjaman melakukan transaksi pinjam meminjam tanpa harus bertemu langsung. Mekanisme pinjam memijam ini dilakukan melalui sistem yang telah disediakan oleh Penyelenggara Fintech Lending, baik melalui aplikasi maupun laman website.

\section{Crowdfunding}

Crowdfunding merupakan tipe fintech dimana sebuah konsep atau produk seperti desain, program, konten, dan karya kreatif dipublikasikan secara umum dan bagi masyarakat yang tertarik dan ingin mendukung konsep atau produk tersebut dapat memberikan dukungan secara finansial. Crowdfunding dapat digunakan untuk mengurangi kebutuhan finansial kewirausahaan dan memprediksi permintaan pasar. 


\section{Pengaturan Fintech di Indonesia}

Beberapa pengaturan terkait mengenai fintech di Indonesia diantaranya:

1. Peraturan Bank Indonesia

No.18/40/PBI/2016 tentang penyelenggaraan pemrosesan transaksi pembayaran.

2. Peraturan Bank

Indonesia

No.19/12/PBI/2017 tentang Penyelenggaraan Teknologi Finansial.

3. Peraturan Anggota Dewan Gubernur No.19/14/PADG/2017 tentang Ruang Uji

Coba Terbatas (Regulatory Sandbox)

Teknologi Finansial.

4. Peraturan Anggota Dewan Gubernur No.19/15/PADG/2017 tentang Tata Cara Pendaftaran, Penyampaian Informasi, dan Pemantauan Penyelenggara Teknologi

Finansial.

Sementara itu, OJK menerbitkan pengaturan yang berkaitan dengan salah satu produk fintech melalui Peraturan Otoritas Jasa Keuangan No.77/POJK.01/2016 tentang Layanan Pinjam Meminjam Uang Berbasis Teknologi Informasi.

\section{Layanan Pinjam Meminjam Berbasis} Teknologi Informasi P2P Lending Syariah di Indonesia.

Penyelengaraan layanan pinjammeminjam berbasis teknologi informasi yang mempergunakan akad syariah berkembang dengan beberapa pilihan kepada para pengguna layanan, baik itu peminjam maupun pihak yang memberikan pinjaman. Skema yang diberikan peminjam maupun pemberi pinjaman dapat disesuaikan dengan kebutuhan mereka, sesuai koridor syariah. Penerapan skema syariah ini dilakukan dengan memperhatikan ketentuan yang ditetapkan oleh regulator agar memberikan pelayanan yang maksimal serta perlindungan dan kepastian bagi pengguna layanan.

Beberapa akad yang di terapkan oleh penyelenggara layanan antara lain akad Wakalah bil Ujrah dan akad Musyarakah. Penyelenggaraan layanan yang dilaksanakan oleh Investree dan Dana Syariah dengan mempergunakan skema syariah. Dalam pelaksaan transaksi syariah lembaga jasa keuangan wajib tunduk pada peraturanperaturan penyelenggaraan layanan berdasar syariah yang dikeluarkan oleh pihak terkait. Peraturan Otoritas Jasa Keuangan (POJK) Nomor 77/POJK.01/2016 yang menjadi dasar penyelenggaraan layanan pinjam meminjam berbasis teknologi informasi. Namun dalam pelaksanaannya masih terdapat hal-hal yang perlu dilengkapi oleh lembaga jasa keuangan yang melaksanakan transaksi berdasar syariah.

Kendati demikian, kegiatan penagihan sering sekali menyebabkan persoalan dimana industri fintech kemudian melakukan perbuatan yang berbahaya bagi konsumennya seperti intimidasi, pencurian dan penyalahgunaan data hingga pelecehan seksual. Oleh karenanya 
pelaksanaan fintech syariah ini wajib memiliki payung hukum sebagai dasar pelaksanaan layanan pinjam-meminjam berbasis teknologi informasi yang berdasarkan syariah. Dasar hukum yang ada saat ini masih Fatwa terkait penyelenggaraan layanan pinjam-meminjam berbasis teknologi informasi No.117/DSNMUI/II/2018 Tentang Layanan Pembiayaan Berbasis Teknologi Informasi Berdasarkan Prinsip Syariah.

Maka perlu ditegaskan tentang perbedaan fintech syariah dan fintech kovensional bahwa ini merupakan tugas besar bagi para pelaku fintech syariah. Kunci nya terletak pada akad berdasarkan prinsip syariah yang digunakan dalam skema transaksi fintech syariah. Dengan mengemukakan keunggulan penggunaan akad dalam fintech syariah, dan kembali menjelaskan akan haramnya keterlibatan kita dalam sistem bunga (yang ada di dalam fintech konvesional) dengan dilandasi dasar fatwa DSN MUI No. 1 Tahun 2004 tentang Hukum Bunga (Interest) yang meliputi:

a. Praktik pembungaan uang saat ini telah memenuhi kriteria riba yang terjadi pada zaman Rasulullah SAW, yakni riba nasi'ah. Dengan demikian, praktek pembungaan uang termasuk salah satu bentuk riba, dan riba haram hukumnya.

b. Praktik pembungaan tersebut hukumnya adalah haram, baik dilakukan oleh Bank, Asuransi, Pasar Modal, Pegadaian,
Koperasi dan Lembaga Keuangan lainnya maupun dilakukan oleh Individu.

Penyelenggaraan layanan wajib memenuhi ketentuan dan menyesuaikan penyelenggaraan layanannya dengan ketentuan syariah yang berkaitan dengan usaha tersebut. Kepatuhan terhadap prinsip syariah merupakan kewajiban bagi lembaga jasa keuangan yang menjalankan usahanya dengan prinsip syariah. Dalam penyelenggaraan kegiatan layanan Lembaga Jasa Keuangan Syariah wajib memperhatikan jaminan kepatuhan syariah (shariah compliance assurance) atas keseluruhan aktivitas penyelenggara Layanan. Hal ini merupakan salah satu yang sangat penting bagi pengguna layanan.

a. Beberapa ketentuan yang dapat digunakan sebagai ukuran secara kualitatif untuk menilai ketaatan syariah bagi penyelenggara layanan pinjam meminjam berbasis teknologi informasi: Akad atau kontrak yang digunakan untuk pengumpulan dan penyaluran pembiayaan sesuai dengan prinsipprinsip Syariah dan aturan Syariah yang berlaku.

b. Dana zakat dihitung dan dibayar serta dikelola sesuai dengan aturan dan prinsip-prinsip syariah.

c. Seluruh transaksi dan aktivitas ekonomi dilaporkan secara wajar sesuai dengan standar akuntansi syariah yang berlaku. 
d. Lingkungan kerja dan corporate culture sesuai dengan syariah.

e. Bisnis usaha yang dibiayai tidak bertentangan dengan Syariah.

f. Terdapat Dewan pengawas Syariah sebagai pengarah syariah atas seluruh kegiatan operasional penyelenggara layanan.

g. Semua berasal dari sumber yang sah dan halal sesuai syariah.

Tabel 1, Perbedaan Fintech P2P konvensional dan Fintech syariah

\begin{tabular}{|c|c|c|}
\hline Fintech & Konvensional & Syariah \\
\hline $\begin{array}{l}\text { Dasar } \\
\text { Hukum }\end{array}$ & 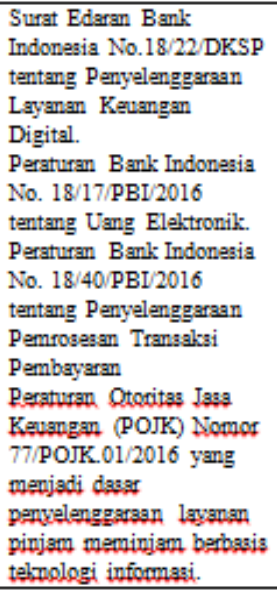 & 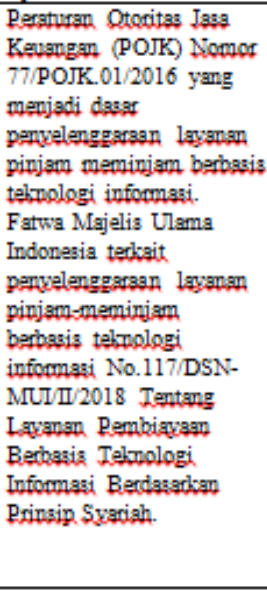 \\
\hline Resilko & $\begin{array}{l}\text { Nasabah alkan } \\
\text { menanggung sepenuhnya } \\
\text { risiko ketika nasabah tidak } \\
\text { memiliki kemampuan } \\
\text { untuk membayar } \\
\text { cicilannya }\end{array}$ & $\begin{array}{l}\text { Dalam sistem pembiaysen } \\
\text { akad syariah kedua belah } \\
\text { pihak baik fintech atsupun } \\
\text { nasabah akan menanggung } \\
\text { risiko tersebut. }\end{array}$ \\
\hline $\begin{array}{l}\text { Ketersediaan } \\
\text { pinjaman }\end{array}$ & Bebas nilai & $\begin{array}{l}\text { Pembiayaen syariah } \\
\text { menggunaksan penawaran } \\
\text { produk pada usaha yang } \\
\text { halal , bisa juga untuk } \\
\text { keperluan tertentu seperti } \\
\text { pendidikan, haji, umroh, } \\
\text { atsupun lainnya }\end{array}$ \\
\hline $\begin{array}{l}\text { Pola } \\
\text { Hubungan }\end{array}$ & Hubungan debitur-lseditur & $\begin{array}{l}\text { Hubungan hukum } \\
\text { Aksd murabahah } \\
\text { Alkad ijarah wa iqtina } \\
\text { Alsad musyaraksh } \\
\text { mutanagishah. }\end{array}$ \\
\hline $\begin{array}{l}\text { Mekanisme } \\
\text { pengawasan }\end{array}$ & $\begin{array}{l}\text { Tidak ada badan } \\
\text { Pengawas }\end{array}$ & $\begin{array}{l}\text { Ada Badan Pengawas } \\
\text { Syariah }\end{array}$ \\
\hline
\end{tabular}

Teknologi finansial syariah saat ini sudah semakin canggih. Banyak orang-orang yang menggunakan manfaatnya untuk membuka usaha online, order online dan transaksi online. Misalnya m-banking, belanja pakaian, belanja kebutuhan, dan lain-lain bisa lewat aplikasi online dan hanya dengan menggunakan touchscreen saja kita sudah mendapatkan apa yang kita inginkan. Kecanggihan tersebut sangat mempermudah kita melakukan transaksi dan belanja serta menguntungkan bagi pelaku usaha untuk mempromosikan produknya, sehingga kita bisa menghemat waktu, tenaga dan modal karena kita tidak perlu lagi mempunyai tempat atau toko untuk membuka usaha kita. Namun, di sisi lain, fintech juga memiliki kendala yang dapat menghambat kemajuan teknologi tersebut.

Perusahaan Fintech Lending berizin dan terdaftar per 6 April 2021 terdapat 146 perusahaan dimana dari penyelenggara berizin terdapat 42 perusahaan jenis usaha konvensional, 3 perusahaan jenis usaha syariah dan satu konvensional dan syariah. Sedangkan 100 lainnya yang masih berstatus terdaftar, yang terdiri dari 94 perusahaan jenis usaha konvensional dan 6 perusahaan jenis usaha syariah. Penyelenggara dengan status berizin dan terdaftar dapat menjalankan bisnis layanan pinjam meminjam yang berbasis teknologi informasi sesuai dengan ketentuan yang berlaku. Namun, penyelenggara yang telah berstatus berizin memiliki perbedaan dengan 
penyelenggara yang masih berstatus terdaftar, diantaranya yaitu: penyelenggara berizin merupakan perusahaan yang telah mendapatkan izin permanen dan memiliki sertifikat Sintem Manajemen Keamanan Informasi SNI/ISO 270001. Penyelenggara terdaftar merupakan perusahaan yang saat ini sedang dalam proses mendapatkan izin permanen dan wajib mengajukan permohonan izin permanen kepada OJK. Saat ini, seluruh penyelenggara terdaftar telah mengajukan permohonan dan sedang dalam proses mendapatkan izin permanen dimaksud.

Dengan jumlah penyelenggara Fintech Lending syariah yang hanya berjumlah 8 perusahaan tentu mempersulit perusahaan tersebut untuk berkembang. Kendala tersebut bisa menyebabkan terhalangnya kemajuan bangsa dan negara. Hal ini dikarenakan masyarakat itu sendiri yang masih berada di culture lag, yaitu masyarakat yang ketinggalan jaman dan tidak mau mengubah pola pikirnya bahkan tidak mau menerima budaya baru yang dianggapnya sebagai budaya asing yang merusak budaya bangsa. Karena bagi masyarakat awam, teknologi saat ini malah membuat addiction (kecanduan) dan hilangnya fungsi sosial.

Hal tersebut yang telah menyebabkan tidak adanya interaksi sosial lagi antar-manusia satu dengan yang lainnya. Misalnya, sebagai makhluk sosial kalau saja pasar dan toko-toko mulai tidak dapat menjadi tempat bersosialisasi lagi padahal manusia diciptakan untuk itu. Maka sangat wajar jika pada umumnya, masyarakat tersebut takut menerima teknologi baru yang bisa menggantikan budaya kita yang sebenarnya.

Penataan Industri fintech Syariah yang dapat mendorong efisiensi berkeadilan tidak lepas dari tanggung jawab suatu negara. Penjelasan prinsip efisiensi-berkeadilan sebagai landasan konstitusional dalam penyelenggaraan demokrasi ekonomi yang dimaksud yaitu:

Pertama, tidak anti terhadap kompetisi dan sistem ekonomi pasar namun tetap dikendalikan oleh pemerintah yang berwenang sehingga menuju pasar yang efisien.

Kedua, tidak anti privatisasi dan mengakui kepemilikan pribadi, artinya peran swasta sebagai pelaku usaha tidak dibatasi selama tidak terkait dengan cabang-cabang produksi yang penting bagi negara dan menguasai hajat hidup orang banyak, serta kepemilikan faktor produksi oleh perorangan dibatasi oleh undang-undang, hukum adat, dan norma kepentingan komunal.

Negara adalah bagian dari kebudayaan manusia, sebagai pemegang kekuasaan tertinggi negara memiliki tanggung jawab untuk melindungi masyarakatnya. Baik itu ancaman terorisme maupun dari kendala-kendala yang menyebabkan kemunduran bagi peradaban ekonominya. Terdapat dua kemungkinan yang 
dapat dijadikan alasan bagi negara agar terbebas dari kewajibannya untuk bertanggungjawab, yakni pembelaan (defences) dan pembenaran (justification). Tanggung jawab negara yang lahir pada tahun 1970 dan 1980 oleh ILC, dimana negara diberikan kategori pembelaan adalah jika:

1. Suatu negara dipaksa oleh negara lain untuk melakukan suatu perbuatan yang dapat dipersalahkan atau melawan hukum;

2. Negara yang melakukan tindakan itu telah mendapatkan persetujuan dari negara yang menderita kerugian;

3. Negara yang melakukan tindakan itu, semata-mata sebagai upaya perlawanan yang diperbolehkan (permissible countermeasure); dan

4. Para pejabat negara tersebut bertindak karena force majeure (keadaan memaksa) atau keadaan yang membahayakan dan tidak bermaksud sama sekali untuk menimbulkan akibat yang membahayakan.

Dari penjelasan diatas dapat kita pahami bahwa negara tidak dapat terbebas dari tanggungjawabnya untuk memenuhi kebutuhan hukum fintech syariah bagi masyarakatnya. Kendala fintech syariah yang lainnya yaitu, fintech konvensional yang terdaftar lebih mudah dan lebih bervariasi sedangkan fintech syariah masih kekurangan modal sehingga kurangnya sumber daya, inovasi produk dan marketing.
Tetapi saat ini Asosiasi Fintech Syariah Indonesia akan ditunjuk oleh Otoritas Jasa Keuangan (OJK) menjadi Self Regulatory Organization (SRO) yang akan membantu regulator untuk mengembangkan sekaligus mengawasi operasional Fintech Syariah. Selain itu, regulator dan industri bersama pengembangan ekosistem yang dapat menunjang literasi dan partisipasi di fintech syariah.

Sinergi atau kolaborasi antar fintech syariah ini harus dipertahankan. Oleh karenanya penting bagi Komite Nasional Keuangan Syariah (KNKS) bersama stakeholder lain yang saat ini sedang menyiapkan Rancangan UndangUndang Ekonomi Syariah yang akan memasukkan peraturan fintech syariah. Jika ini sudah dikeluarkan juga akan menjadi salah satu daya tarik bagi investor. Selain itu, pemerintah disini sebenarnya sangat berperan penting bagi fintech syariah, pemerintah juga harusnya lebih kuat mendukung infrastruktur yang ada, apalagi Pemerintah sudah mencanangkan agar dimasa depan Indonesia menjadi pusat ekonomi syariah dunia.

\section{Implementasi Penggunaan Kecerdasan \\ Buatan Berdasarkan Prinsip Syariah.}

Sebagai salah satu negara dengan penduduk muslim terbesar di dunia, layanan keuangan digital atau financial technology (fintech) syariah memiliki potensi yang besar untuk semakin bertumbuh. Asosiasi Fintech 
Syariah Indonesia (AFSI) yang baru berusia satu tahun, saat ini mencatat anggota yang teregistrasi baru mencapai 55 anggota.

Ketua Umum Asosiasi Fintech Syariah Indonesia, Ronald Wijaya menyampaikan, dari

55 fintech syariah tersebut, 12 anggotanya merupakan penyedia layanan Peer-to-Peer Lending (P2P) yang diatur dalam Peraturan Otoritas Jasa Keuangan (POJK) 77/POJK.O1/2016, sementara sisanya masuk dalam POJK Inovasi Keuangan Digital. Namun, Secara keseluruhan, fintech syariah sebetulnya memiliki 100 anggota. Tetapi yang sudah menjalankan kewajiban seperti membayar iuran anggota, melengkapi akadnya, secara resmi ada 55 anggota. Selain itu, kendala fintech syariah yaitu harus mempunyai DPS atau Dewan Pengawas Syariah, sedangkan disisi lain hal tersebut sangat memberatkan karena biayanya cukup besar sedangkan fintech syariah kebanyakan startup pemula dengan modal yang masih terbatas.

Peran Dewan Pengawas Syariah dalam penyelenggaraan Fintech Syariah, yaitu: 1) sebagai penasihat dan pemberi saran kepada penyelenggaran Fintech Syariah mengenai halhal yang berkaitan dengan aspek syariah. 2) sebagai mediator antara penyelenggara Fintech Syariah dengan DSN-MUI dalam mengkomunikasikan usulan pengembangan produk dan layanan jasa keuangan yang memerlukan kajian dan fatwa dari DSN-MUI dan 3) sebagai perwakilan DSN-MUI yang ditempatkan pada perusahaan Fintech Syariah.

Beberapa demo bahkan kasus bunuh diri terjadi di masyarakat dikarenakan fintech yang berbentuk pinjaman online yang menjerat kalangan masyarakat menengah ke bawah. Kehadiran fintech syariah yang berlandaskan pada prinsip syariah diharapkan mampu memperbaiki tujuan awal dari kehadiran fintech yang seharusnya memudahkan masyarakat dalam melaksanakan kegiatan dan transaksi ekonomi yang berlandaskan prinsip syariah. Peluang dan tantangan fintech syariah di Indonesia menjadi penting untuk dipelajari seiring dengan perkembangan pesat fintech syariah di Indonesia.

Pemenuhan prinsip syariah dalam penyelenggaraan Fintech syariah difasilitasi oleh pemerintah untuk mendorong perkembangan fintech syariah di Indonesia. Solusinya adalah dengan cara dibuatkan alternatif lain misalnya satu DPS (Dewan pengawas Syariah) bisa menjadi pengawas di beberapa fintech syariah, setidaknya untuk yang belum terdaftar sehingga fintech syariah mempunyai infrastruktur yang sesuai dengan regulasi OJK. Tentu sumber daya yang amanah dan ahli dalam bidang syariah menjadi kebutuhan utama. AI dapat membantu proses analisis dan sinkronisasi aturan secara lebih cepat dan efisien, disinilah potensi AI dapat dikembangkan lebih jauh lagi. sehingga fintech 
syariah tidak menyulitkan masyarakat umum pada proses dan biaya yang mahal ketika melakukan transaksi layanan pinjam-meminjam.

Kendala lainnya adalah terkait proses pendaftaran perizinan ke Otoritas Jasa Keuangan yaitu yang memakan waktu cukup lama dibandingkan pengajuan perizinan fintech konvensioal. Ditambah lagi dengan pengetahuan masyarakat mengenai fintech yang masih terbatas, apalagi terkait fintech syariah. Namun, hal tersebut harus menjadi semangat untuk terus berkembang karena potensi pertumbuhan fintech syariah sangat besar sebab Indonesia merupakan negara dengan penduduk muslim terbanyak. Kita juga merupakan digital ready country dengan jumlah pengguna internet yang sangat besar.

Perlindungan bagi pengguna layanan harus disesuaikan dengan prinsip syariah merupakan aspek yang mendasar dan menjadikan pembeda antara Penyelenggara layanan konvensional dengan penyelenggara layanan berdasar syariah. karena dalam syariah tidak hanya profit oriented, namun juga falah oriented dimana tidak hanya keuntungan semata mata yang di peroleh namun kemenangan didunia dan di akhirat menjadi salah satu yang ingin dicapai dalam penyelenggaraan layanan.

Kendati demikian, untuk mencapai tujuan tersebut lembaga jasa keuangan syariah membuat pengaturan mengenai kepatuhan syariah (syariah compliance). Kepatuhan
Syariah merupakan prinsip utama yang harus dipenuhi sekaligus pembeda dengan Penyelenggara Layanan jasa keuangan yang lain (Konvensional) sebagai bentuk perlindungan hukum preventif bagi para pengguna jasa layanan. Makna kepatuhan syariah dalam bank syariah secara konsep sesungguhnya adalah penerapan prinsip-prinsip perikatan Islam, syariah, dan tradisinya ke dalam transaksi keuangan serta bisnis lain yang terkait secara konsisten.

Menjadikan syariah sebagai kerangka kerja bagi sistem dan keuangan penyelenggara jasa keuangan syariah dalam alokasi sumber daya, manajemen, produksi, aktivitas pasar modal, dan distribusi kekayaan. utamanya kepatuhan syariah dalam layanan pinjam meminjam berbasis teknologi informasi adalah tercipta dan terpenuhinya budaya kepatuhan pada prinsip syariah serta perundang-undangan yang berlaku. dalam bidang muamalah (transaksi fintech berbasis syariah) termasuk moral etika dalam setiap aktivitasnya,

Menurut Professor Klause Schwab salah satu pendiri World Economic Forum di Davos menegaskan, bahwa dunia sedang mengalami revolusi industri keempat, yang bukan merupakan revolusi dalam proses produksi saja, melainkan revolusi sistem. Dia mengingatkan: "if we do not want to be dominated by technology, we have to become a more human society”. Professor Klause memang tidaklah 
berlebihan, karena teknologi secara tak terhindarkan akan merubah pola hubungan antar-manusia dan karena itu pula merubah pola hubungan-hubungan dari subjek hukum itu sendiri.

Berdasarkan uraian diatas, maka dapat dipahami bahwa penggunaan AI dalam proses pengawasan tidak serta merta dapat menggantikan peran dan fungsi dewan pengawas syariah. Penggunaan AI dalam proses pengawasan diposisikan hanya sebatas alat bantu dalam kegiatan pengharmonisasian pada proses penyelenggaraan layanan pinjaman. Penggunaan AI tersebut diharapkan dapat memprediksi potensi disharmoni antara hukum Islam dan berbagai,

\section{SIMPULAN}

Dari hasil pembahasan diatas, dapat ditarik kesimpulan sebagai berikut: Pertama, memakai beberapa aturan dan hukum bentukan Belanda sampai saat ini masih tetap dilakukan Indonesia. Namun setelah kemerdekaan Indonesia, berlaku UUD 1945 sebagai dasar konstitusi Indonesia dengan tujuan menunjukan pada dunia bahwa bangsa Indonesia telah merdeka seutuhnya. Penggunaan hukum peninggalan Belanda hanya untuk agar tidak adanya kekosongan hukum di Indonesia dan tentunya Indonesia secara pelan-pelan sudah mewujudkan hukum nasional sendiri. Kedua, Setelah kemerdekaan Indonesia, Para founding father Indonesia berkeinginan besar untuk menciptakan dan membentuk hukum nasional sendiri, yang tentunya berlandaskan kepribadian bangsa melalui pembentukan hukum nasional. Ketiga, Membahas tipologi hukum di Indonesia menurut Nonet dan Selznick, hukum di Indonesia sangat dekat dengan tipe hukum represif dimana pembentukan dan penerapan hukum banyak dipengaruhi oleh kepentingan politik dan kekuasaan, kekuasaan dan berpolitik yang otoriter dapat menciptakan hukum yang bersifat represif. Dampaknya bukan saja menciptakan rasa tidak adil terhadap masyarakat, adanya hukum seperti itu juga tentu akan menjadi momok bagi kalangan masyarakat itu sendiri. Disarankan juga agar pemerintah dalam membuat suatu perundang-undangan agar lebih mengedepankan kepentingan masyarakat banyak dan tentunya harus berpihak pada rakyat-rakyat kecil. Kemudian daripada itu, dalam penegakan hukum harus ditegakan seadil-adilnya tanpa memandang siapa orang yang diadili tersebut, jangan sampai masyarakat berpikir bahwa hukum di Indonesia hanya tajam kebawah saja namun tumpul apabila dihadapkan ke atas. 


\section{DAFTAR PUSTAKA}

\section{Jurnal}

Agus Rahardjo, 2001. Fleksibilitas Hukum (Sikap Hukum Menghadapi Perkembangan Jaman), Jurnal Kosmik Hukum, Vol. 1, No. 1.

Henry Arianto, 2010. Hukum Responsif Dan Penegakan Hukum Di Indonesia, Lex Jurnalica Vol. 7 No.2.

Imam Mahdi, 2016. Ilmu Hukum dan Perkembangannya (Kajian Khusus Hukum Normatif), Jurnal Nuansa Vol. IX, No. 2.

Renny NS Koloay, 2016. Perkembangan Hukum Indonesia Berkenaan dengan Teknologi Informasi dan Komunikasi, Jurnal Hukum Unsrat Vol. 22, No. 5.

Salman Luthan, 2007. Hubungan Hukum dan Kekuasaan, Jurnal Hukum. Vol. 14. No. 2.

\section{Buku}

Jimly Asshiddiqie. 2005. Hukum Tata Negara \& Pilar-Pilar Demokrasi Serpihan Pemikiran Hukum, Media dan HAM. Jakarta: Konstitusi Press.

Moh. Mahfud MD. 2009. Konstitusi dan Hukum dalam Kontroversi Isu. Jakarta: Rajawali Pers. Satjipto Rahardjo. 2005. Ilmu Hukum. Bandung: Citra Aditya Bakti.

Utrecht. 1962. Pengantar Hukum Administrasi Negara Indonesia. Jakarta: Ichtisar. 